DOI: $10.6060 / \mathrm{mhc} 200286 \mathrm{t}$

\title{
Synthesis and Characterization of Tetrakis(allyloxy) Substituted Zn(II), Pt(II) and Pd(II) Phthalocyaninates
}

\author{
I. D. Burtsev, ${ }^{a}$ Ya. B. Platonova, ${ }^{\mathrm{a}, \mathrm{b}}$ A. N. Volov, ${ }^{\mathrm{a}}$ and L. G. Tomilova ${ }^{\mathrm{a}, \mathrm{b}}$ \\ ${ }^{a}$ Department of Chemistry, Lomonosov Moscow State University, 119991 Moscow, Russian Federation \\ ${ }^{\mathrm{b}}$ Institute of Physiologically Active Compounds, Russian Academy of Sciences, 142432 Chernogolovka, Russian \\ Federation \\ ${ }^{\circledR}$ Corresponding authorE-mail: tom@org.chem.msu.ru
}

\begin{abstract}
2(3)-Tetrakis(allyloxy) substituted phthalocyanine complexes of Zn(II), Pt(II) and Pd(II) have been obtained from a phthalocyanine ligand in high yields (up to $90 \%$ ). Both thermal and microwave irradiation techniques were successfully applied for complexes of Pd(II). Platinum and palladium complexes were synthesized for the first time and the new method for the synthesis of zinc complex was proposed. The obtained compounds were characterized by a combination of MALDI/TOF mass spectrometry, UV-Vis, and ${ }^{195} \mathrm{Pt}$ NMR spectroscopies. Photochemical properties of platinum(II) phthalocyanine were investigated. It was shown that this complex maintained high production of singlet oxygen and potentially can be used in photodynamic therapy.
\end{abstract}

Keywords: Phthalocyanines, microwave irradiation, UV-Vis spectroscopy, ${ }^{195} \mathrm{Pt}$ NMR spectroscopy, zinc(II), platinum(II), palladium(II).

\section{Синтез и характеристика тетракис(аллилокси)замещенных фталоцианинатов Zn(II), Pt(II) и $\operatorname{Pd}($ II)}

\author{
И. А. Бурцев, ${ }^{a}$ Я. Б. Платонова, ${ }^{\mathrm{a}, \mathrm{b}}$ А. Н. Волов, ${ }^{\mathrm{a}}$ ᄉ. Г. Томилова ${ }^{\mathrm{a}, \mathrm{b}}$

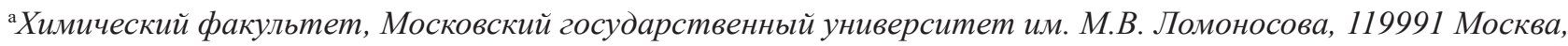 \\ Россия \\ ${ }^{\mathrm{b}}$ Институт физиологически активных вещчеств РАН, 142432 Черноголовка, Россия \\ ${ }^{\circledR}$ E-mail: tom@org.chem.msu.ru
}

В работе были получены Zn(II), Pt(II) и Pd(II) комплексы 2(3)-тетракис(аллилокси)замещенных фталочиианинов с высокими выходами (до 90 \%). Для комплексов с палладием(II) успешно применялись как сплавление, так и микроволновое излучение. Комплексы с платиной и палладием получены впервые, предложен новый метод синтеза ичинкового комплекса. Полученные соединения охарактеризованы комбинацией MALDI/TOF массспектрометрии, электронной и ${ }^{195}$ Pt ЯМР спектроскопии. Были исследованы фотохимические свойства фталоциианната платины(II), который способен в высокой степени генерировать синглетный кислород и потенциильно может быть использован в фотодинамической терапии.

Ключевые слова: Фталоцианины, микроволновое излучение, электронная спектроскопия, ${ }^{195} \mathrm{Pt} \quad$ ЯMP спектроскопия, цинк(II), платина(II), палладий(II). 
Photodynamic therapy of cancer (PDT) is useful method for the treatment of various forms of oncology. ${ }^{[1]}$ Phthalocyanine complexes are the most promising photosensitizers (PS) for $\mathrm{PDT}^{[2,3]}$ due to their advantages over other macroheterocyclic compounds. These compounds are characterized by absorbance in the region of 600-800 nm in the visible spectrum, corresponding to the therapeutic area, and high stability during light exposure. Platinum(II) phthalocyanine complexes are characterized by a high lifetime of a triplet state, ${ }^{[4]}$ due to which they are potential candidates for use in PDT, as reported with some other platinum complexes. ${ }^{[5,6]}$ One of the main problems of phthalocyanine applications in PDT is their poor solubility in physiological media. For this reason, research is currently being conducted in the field of search for amphiphilic water-soluble compounds, particularly the combination of hydrophobic macrocyclic structure of phthalocyanines with hydrophilic carbohydrate fragments. ${ }^{[7]}$ PS in clinical use often show low selectivity and insufficiently specific distribution in the organism. ${ }^{[8,9]}$ In this regard, targeted cancer therapy is actively developing, including in the PDT method. The structure of the PS is being combined with targeted particles, with a linker or directly. The introduction of linker into the structure of targeted molecules increases the effectiveness of drugs ${ }^{[10,11]}$ and provides binding to vectors, such as peptides, nanobodies or carbohydrates, ${ }^{[12-14]}$ for the formation of conjugates, widely used in modern therapy for the targeted delivery of the drug to tumor tissues. An actual task of our research is the synthesis of phthalocyanine metal complexes, modified with linkers of allyl type as the peripheral substituents.

We report here the synthesis of several 2(3)-tetrakis(allyloxy) substituted metallophthalocyanines from the corresponding phthalocyanine ligand, which was obtained previously from 4-(prop-2-enyloxy)phthalonitrile similarly to known procedure. ${ }^{[15]}$

$\mathrm{Zn}(\mathrm{II}), \mathrm{Pt}(\mathrm{II})$ and Pd(II) were chosen as the central metal ions. Zinc complex usually is used as a standard compound in photochemical studies of phthalocyanine-based PSs. ${ }^{[16]}$

For the subsequent creation of linkers containing a double bond between the aromatic phthalocyanine system and carbohydrate fragments in the described complexes, peripheral allyloxy groups were introduced by analogy with Refs. ${ }^{[17,18]}$
Zinc phthalocyanine ( $\left.{ }^{\mathrm{O}-\mathrm{Allyl}} \mathrm{PcZn}\right)$ was synthesized by interaction of the initial phthalocyanine ligand $\left({ }^{\mathrm{O}-\mathrm{Allyl}} \mathrm{PcH}_{2}\right)$ with zinc acetate dihydrate $-\mathrm{Zn}(\mathrm{OAc})_{2} \cdot 2 \mathrm{H}_{2} \mathrm{O}-$ in the presence of lithium methoxide (MeOLi) in isoamyl alcohol (see Supporting Information, SI). Before adding zinc salt, it was decided to convert ${ }^{\text {O-Allyl }} \mathrm{PcH}_{2}$ into the dianion form ( ${ }^{\mathrm{O}-\mathrm{Allyl}} \mathrm{Pc}^{2-}$ ) by interaction with MeOLi (UV-Vis spectral control). The attempts have been made to use 1,8-diazabicyclo[5.4.0] undec-7-ene (DBU) as a base, but in this case it was not possible to convert ${ }^{\mathrm{O}-\mathrm{Ally}} \mathrm{PcH}_{2}$ into a dianion form. After the addition of zinc acetate, the reaction was carried out by heating under argon for 1.5 hours and desired complex was obtained with $90 \%$ yield.

It should be noted that the zinc complex was also obtained by the method ${ }^{[15]}$ based on 4-(prop-2-enyloxy) phthalonitrile with $38 \%$ yield. Comparison of methods shows that the proposed method is characterized by a much shorter reaction time (1.5 hours compared to 16 hours) and less time-consuming method of purification - column chromatography was not required.

In the synthesis of ${ }^{\text {O-Allyl }} \mathrm{PcPt}(\mathrm{II})$ and ${ }^{\mathrm{O}-\mathrm{Allyl}} \mathrm{PcPd}(\mathrm{II})$, the above method of obtaining a zinc complex did not give results due to the insufficient high temperature for the complexation and low solubility of $\mathrm{PtCl}_{2}$ and $\mathrm{PdCl}_{2}$ in isoamyl alcohol. In connection with this a new method was developed. The complex was synthesized from ${ }^{\mathrm{O}-\mathrm{Allyl}} \mathrm{PcH}_{2}$ and $\mathrm{PtCl}_{2}$ or $\mathrm{PdCl}_{2}$ in the presence of $\mathrm{DBU}$ in benzonitrile. An important feature of this reaction is the preliminary generation of the $\mathrm{PtCl}_{2}(\mathrm{PhCN})_{2}$ or $\mathrm{PdCl}_{2}(\mathrm{PhCN})_{2}$ complexes obtained by the interaction of chlorides with benzonitrile, which increases its solubility in the reaction medium. After addition of ${ }^{\text {O-Allyl }} \mathrm{PcH}_{2}$, the reaction was carried out by heating under argon for 8 hours and the target complex was obtained with $85 \%$ yield. Both thermal and microwave irradiation techniques were successfully applied for complexes of Pd(II) (Scheme 1).

In the UV-Vis spectra of the complexes intense absorption is observed in the $340-350 \mathrm{~nm}$ region and at the $Q$-band (680-690 nm).

The structure of the prepared complexes was proved by MALDI-TOF mass spectrometry.

In the spectrum of the ${ }^{\text {O-Allyl }} \mathrm{PcZn}$ sample (Figure S1) signal $m / z=800.066$ is observed, corresponding to the claimed structure and the signal $\mathrm{m} / \mathrm{z}=760.029$, which corresponds
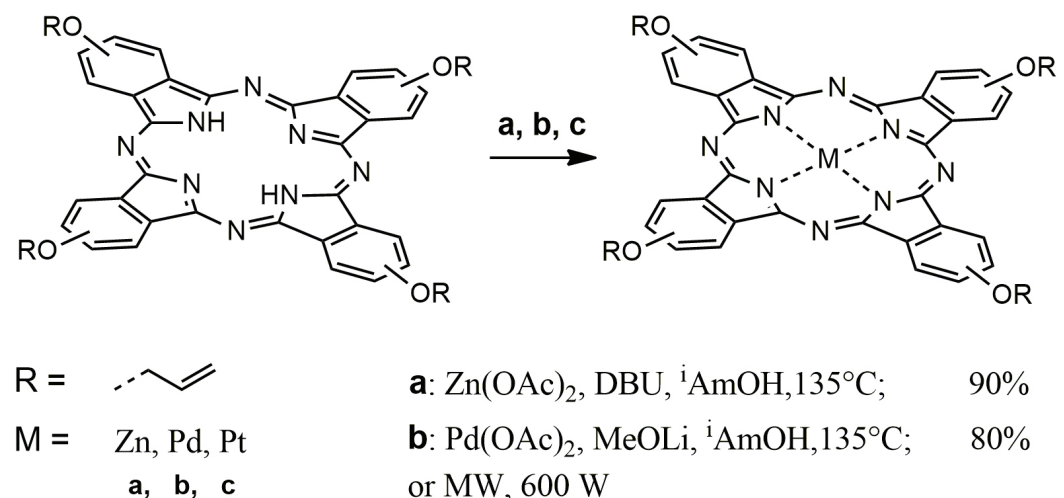

a: $\mathrm{Zn}(\mathrm{OAc})_{2}, \mathrm{DBU},{ }^{\mathrm{i}} \mathrm{AmOH}, 135^{\circ} \mathrm{C}$;

$90 \%$

a, b, c

b: $\mathrm{Pd}(\mathrm{OAc})_{2}, \mathrm{MeOLi},{ }^{i} \mathrm{AmOH}, 135^{\circ} \mathrm{C}$;

$80 \%$ or MW, $600 \mathrm{~W}$

c: $\mathrm{PtCl}_{2}, \mathrm{DBU}, \mathrm{PhCN}, 160^{\circ} \mathrm{C}$;

$85 \%$

Scheme 1. Synthesis of ${ }^{\text {o-Allyl}} \mathrm{PcZn}$, ${ }^{\text {o-Allyl }} \mathrm{PcPt}(\mathrm{II})$ and ${ }^{\mathrm{O}-\mathrm{Ally} l} \mathrm{PcPd}(\mathrm{II})$ complexes. 

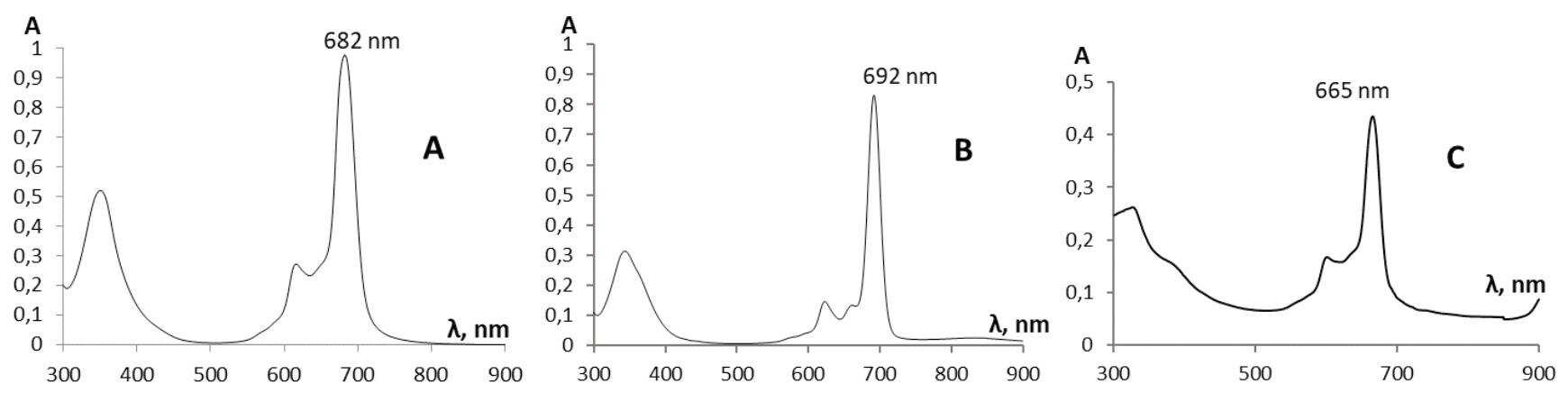

Figure 1. UV-Vis spectra of ${ }^{\text {O-Allyl }} \mathrm{PcZn}$ (A), ${ }^{\text {O-Allyl }} \mathrm{PcPt}(\mathrm{II})$ (B) and ${ }^{\text {O-Allyl}} \mathrm{PcPd}(\mathrm{II})$ (C) in THF.

Table 1. Experimental data for determination of singlet oxygen quantum yield for platinum(II) phthalocyanine and standard compound.

\begin{tabular}{ccccccc}
\hline$\Delta D_{c}, \Delta D_{S t}{ }^{*}$ & $D_{c}, D_{S t}{ }^{*}$ & $t_{i r}, \mathrm{~s}$ & $I$, microwatt & $\lambda, \mathrm{nm}$ & $\varphi_{\Delta}$ & Compound \\
\hline 0.142 & 0.120 & 120 & 108 & 692 & $0.74 \pm 0.07$ & ${ }^{\text {o-Allyl } \mathrm{PcPt}(\mathrm{II})}$ \\
\hline 0.110 & 0.028 & 600 & 104 & 512 & $0.65 \pm 0.05$ & Standard (TPP) \\
\hline
\end{tabular}

*The values averaged over several experiments are shown.

to the particle $\mathrm{ZnPc}(\mathrm{O}-\mathrm{Allyl})_{3} \mathrm{O}^{-}$, formed as a result of fragmentation while the spectrum registration. The spectrum of ${ }^{\text {O-Allyl }} \mathrm{PcPt}(\mathrm{II})$ sample (Figure S2) also contains the desired signal at $\mathrm{m} / z=931.106$, and the signal at $\mathrm{m} / z=767.152$ corresponding to the $\mathrm{PcPt}_{(\mathrm{II}) \mathrm{O}^{-}}$particle formed as a result of fragmentation. Isotopic distributions for complexes correspond to theoretically calculated ones.

Platinum(II) phthalocyanine complex was characterized by ${ }^{195} \mathrm{Pt}$ NMR spectroscopy (Figure S3). The spectrum contains signal at $\delta=-3200.664 \mathrm{ppm}$, which is in agreement with the literature data. ${ }^{[19,20]}$

The object of photochemical research in the work was platinum(II) phthalocyanine ${ }^{\mathrm{O}-\mathrm{Allyl}} \mathrm{PcPt}(\mathrm{II})$.

The phosphorescence lifetime estimated using the phosphoroscope method described in ${ }^{[21]}$ is $0.8 \mathrm{~ms}$. The phosphorescence measurements show that the triplet states of the studied compounds are significantly higher than the singlet ${ }^{1} \Delta_{\mathrm{g}}$-state of oxygen, which is a prerequisite for high photosensitizing activity.

The quantum yield of singlet oxygen generation was determined by a relative method using a chemical trap (diphenylisobenzofuran, DPBF) and tetraphenylporphine (TPP) as the standard compound (see Supporting Information). The experimental data and the value of singlet oxygen quantum yield for platinum(II) phthalocyanine are presented in Table 1.

In conclusion, we have obtained 2(3)-tetrakis(allyloxy) substituted metallophthalocyanine complexes of $\mathrm{Zn}(\mathrm{II})$, $\mathrm{Pt}(\mathrm{II})$ and $\mathrm{Pd}(\mathrm{II})$ from the phthalocyanine ligand. Platinum complex was synthesized for the first time with $85 \%$ yield and characterized by physicochemical methods. Both thermal and microwave irradiation techniques (600 W, 8 min) were successfully applied for complexes of Pd(II). For the synthesis of zinc complex a new method was proposed with a higher yield $(90 \%)$ compared with the literature.
Values of singlet oxygen quantum yields were obtained for the platinum(II) complex, showing a significant advantage relative to the standard compound (TPP).

Acknowledgements. We are grateful for main financial support from the Russian Science Foundation (Project 18-7300216). Spectral investigations were supported by ERA.Net RUS Plus Plasmon Electrolight and FWO funding (RFBR No. 18-53-76006 ERA).

\section{References}

1. Dolmans D.E.J.G.J., Fukumura D., Jain R.K. Nat. Rev. Cancer 2003, 3, 380-387.

2. Yu L., Wang Q., Yeung K.-W., Fong W.-P., Lo P.-C. Chem. Asian J. 2018, 13, 3509-3517.

3. Zhang J., Jiang C., Longo J.P.F., Azevedo R.B., Zhang H., Muehlmann L.A. Acta Pharm. Sin. B 2018, 8(2), 137-146.

4. Che Y., Yang W., Tang G., Dumoulin F., Zhao J., Liu L., İşci Ü. J. Mater. Chem. A 2018, 6, 5785-5793.

5. Doherty R.E., Sazanovich I.V., McKenzie L.K., Stasheuski A.S., Baggaley E., Bottomley S. et al. Sci. Rep. 2016, 6, 22668.

6. Zhao J., Wu W., Sun J., Guo S. Chem. Soc. Rev. 2013, 42(12), 5323-5351.

7. Aggarwal A., Singh S., Zhang Y., Anthes M., Samaroo D., Gao R., Drain C.M. Tetrahedron Lett. 2011, 52, 5456-5459.

8. Moriwaki S., Misawa J., Yoshinari Y., Yamada I., Takigawa M., Tokura Y. Photodermatol. Photoimmunol. Photomed. 2001, 17(5), 241-243.

9. Allison R.R., Sibata C.H. Photodiagnosis Photodyn. Ther. 2010, 7(2), 61-75.

10. Steiner M., Hartmann I., Perrino E., Casi G., Samatanga B., Jelezarov I. et al. Chem Sci. 2013, 4, 297-302.

11. Peng Z.-H., Sima M., Salama M.E., Kopeckova P., Kopecek J. J. Drug Target 2013, 21(10), 968-980. 
12. Park C.-K., Kim Y.H., Hwangbo S., Cho H. Int. J. Nanomedicine 2017, 12, 8185-8196.

13. Heukers R., Van Bergen en Henegouwen P., Oliveira S. Nanomed. Nanotechnol. 2014, 10(7), 1441-1451.

14. Zheng X. Pandey R.K.P. Anti-Cancer Agents Med. Chem. 2008, 8, 241-268.

15. Gorlach B., Hellriegel C., Steinbrecher S., Yuksel H., Albert K., Plies E., Hanack M. J. Mater. Chem. 2001, 11, 3317-3325.

16. Nas A., Kantekin H., Durmuş M., Gümrükçüoğlu N. J. Lumin. 2014, 154, 15-21.
17. Zhang F.L., Huang Q., Zheng K., Li J., Liu J.Y., Xue J.P. Chem. Commun. 2013, 49(83), 9570-9572.

18. Khan T.K., Bröring M., Mathura S., Ravikanth M. Coord. Chem. Rev. 2013, 257(15-16), 2348-2387.

19. Still B.M., Anil Kumar P.G., Aldrich-Wright J.R., Price W.S. Chem. Soc. Rev. 2007, 36, 665-686.

20. Wang Y.-C., Chen M.-Y., Wu H.-Y., Chen J.-H., Wang S.-S., Tung J.-Y. Polyhedron 2014, 67, 73-80.

21. Krasnovskii A.A. Photochem. Photobiol. 1979, 29(1), 2936.

Received 30.05.2020

Accepted 10.06.2020 